chondria, damage to such an enzyme had occurred. Other explanations are however possible and future work may reveal which is correct.

The work described in this paper was carried out as part of the programme of the Food Investigation Organization of the Department of Scientific and Industrial Research.

\title{
REFERENCES
}

Bonner, J. \& Millerd, A. (1953). Arch. Biochem. Biophys, 42, 125

Isherwood, F. A., Chen, Y. T. \& Mapson, L. W. (r953). Nature, Lond., r7r, 348.

Smith, F. G. (1952). Plant Physiol. 27, 736.

Smythe, C. V. \& King, C. G. (1942). $\mathscr{F}$. biol. Chem. I42, 529.

\section{Chairman's Summing-up}

\section{By Leslie J. Harris, Dunn Nutritional Laboratory, University of Cambridge and Medical Research Council}

On behalf of The Nutrition Society, I wish to thank very warmly those who have presented such an interesting and authoritative series of communications, and particularly the distinguished experts from overseas who have come specially to Britain in order to participate in the symposium.

High credit is due to the organizers of this most useful, and indeed historic meeting, namely to Dr C. P. Stewart and Dr A. P. Meiklejohn. Everyone present is grateful also to Drs Guthrie and Stewart for having undertaken the re-issue and editing of Lind's Treatise of the Scurvy; it has added greatly to the interest of the occasion.

Dr King in his paper has alluded in passing to the period, a good many years ago, when he was a young research worker at the Biochemical Laboratory in Cambridge, England; but he was altogether too generous in mentioning the episode which, I must confess, I had myself now almost completely forgotten, namely the first recorded occasion, apparently, when the suggestion had been put forward that vitamin $\mathrm{C}$ might prove to be identical with the then newly-isolated 'hexuronic acid'! I do recall however that, during the period he refers to, there were in that Institute several young American workers, some of whom have since become distinguished leaders in the fields of nutrition and biochemistry, including, for example, C. G. King and C. A. Elvehjem; they were regular attenders at the advanced lecture courses, including incidentally my own on vitamins and nutrition, and what I do distinctly remember is that one of the American guests had, on some occasion, expressed his own preference for the lectures given by Sir Frederick Hopkins: 'The other lecturers', he said, 'tell you all about the dope that is known, but "Hoppy" tells you all about the dope that isn't known!' I would like to-day to take my cue from that last remark, and, in opening the discussion, draw attention to what seem to me to be some of the principal gaps still remaining in our knowledge about vitamin $\mathrm{C}$. 
OUTSTANDING GAPS

Three such gaps at least are specially noticeable, relating to (I) requirements, (2) distribution, and (3) mode of action.

\section{(1) Vitamin $C$ requirements}

There is as yet no universal agreement about the amount of vitamin $\mathrm{C}$ required daily by a man for maintaining health. We do know that as small a quantity of ascorbic acid as Io $\mathrm{mg} /$ day, or somewhat less, is sufficient to prevent scurvy. But we also know, and it is a familiar observation to everyone who has carried out vitamin assays on animals, that there is generally a wide gap between 'the minimum' and 'the optimum'- that is to say, between the relatively small amount of any vitamin needed to prevent actual lesions of frank deficiency disease and the much larger amount needed to promote full health, as measured by a maximal growth response in the young animal, and by normal physiological function.

\section{Avitaminosis and hypovitaminosis}

With regard to vitamin $\mathrm{C}$, the arguments in favour of this view, that the optimum may be widely separated from the minimum, can be marshalled under several headings.

'Sub-scurvy' in experimental animals. Tests on guinea-pigs do indeed prove that the quantity of vitamin $\mathrm{C}$ needed to prevent so-called 'clinical' signs of scurvy is considerably less than that necessary to secure the full potentialities of growth in the young animal, or to maintain, for example, the normal functioning of the odontoblasts. The curve of response is in fact logarithmic.

Presumptive advantages of 'saturation'. Again, it has been argued that all other animal species, so far as is known, apart only from primates and guinea-pigs, can synthesize vitamin $\mathrm{C}$ in the body and do not need it in their diet, and that it seems a noteworthy fact that in such species Nature has arranged to maintain a state of 'saturation'. Therefore, it is not unreasonable to suppose, as King and others have, that for human beings likewise a state of saturation may be both natural and desirable. There is reason to think, for example, that an intake of vitamin $\mathrm{C}$ appreciably above the mere 'minimum' (or scurvy-preventing dose) is needed to promote the optimal healing of wounds.

Absence of direct proof. On the other side, we are forced to admit that however attractive the presumptive evidence may seem, or however useful a safeguard it undoubtedly is to provide a liberal intake of vitamin $\mathrm{C}$ if only in order to ensure a reasonable margin of safety, nevertheless, we have as yet no means of definitely proving that a man is in better health for receiving say $30 \mathrm{mg}$ of ascorbic acid daily (the League of Nations Standard of Requirement (League of Nations: Technical Commission on Nutrition, 1938) instead of $10 \mathrm{mg} /$ day (the approximate scurvypreventing dose), and still less direct evidence have we for insisting on an allowance of up to $5^{\circ}$ or $75 \mathrm{mg}$, to meet some of the proposed American standards (e.g. (U.S.A.) National Research Council, 1948).

Need for functional tests. This brings me to the point that the one thing that 
would help more than anything else, in settling this controversy about the requirements, would be to have new functional tests developed, to demonstrate the effect of minor degrees of deficiency. Whereas for some other vitamins such tests are already in existence, for vitamin $C$ they are still lacking and are most urgently needed. An example of the kind of test $I$ have in mind is the measurement of dark adaptation for vitamin $A$, which will permit the diagnosis of a mild degree of deficiency of this vitamin before any clinical signs have become evident at all. Similarly, for vitamin $\mathrm{B}_{1}$, the carbohydrate tolerance (pyruvate clearance) test originated by Banerji and myself (Banerji \& Harris, 1939), and applied by McCollum and others in America and elsewhere, will give evidence of some impairment in vitamin $B_{1}$ function when the deficiency is still too slight to produce the more obvious clinical manifestations of disease (see, for example, Shils, Day \& McCollum, I94I; Bueding, Stein \& Wortis, I94I ; Harris, I940; Williams, Mason \& Wilder, I 943).

Likewise for vitamin $\mathrm{C}$ we must look forward to seeing some functional stresstest devised--possibly (bearing in mind Dr Crandon's observations (Crandon, Mikal \& Landeau, r953)) it may be some kind of a local stress reaction. Only when such tests are available will it become possible to detect minor degrees of deficiency in man, and hence to know what is his real optimal requirement.

\section{(2) Distribution}

Another outstanding puzzle about vitamin $\mathrm{C}$ is to know why it is present in such relatively large amounts in some fruits, or in certain plant and animal tissues, and yet is almost entirely absent from other, and apparently analagous, fruits or tissues. This unevenness in its distribution would seem to be almost fortuitous. Are we then to inquire teleologically, what is 'the purpose' of these large amounts of vitamin $\mathrm{C}$ in some sites and the smaller amounts in others closely similar; or are we to regard it, as it almost appears to be, as just a biochemical accident? We can do little more than state the question, for there appears as yet to be little or no hint of the answer.

\section{(3) Mode of action}

We are still largely in the dark also about the physiology and biochemistry of vitamin $\mathrm{C}$ action. We cannot yet point to any precisely defined coenzyme system, such as is possible with various vitamins of the B group.

The known facts

What is known about vitamin $\mathrm{C}$ action can be summarized (for the greater part) under three headings, as follows:

(a) Reducing action. Although it has been shown that vitamin $\mathrm{C}$, by reason of its reducing activity, is able to participate in, or to stimulate, a large number of chemical reactions, this action seems largely unspecific, for other reducing agents can often replace the vitamin. In this direction, then, we are not much nearer explaining the characteristic action of the vitamin in preventing scurvy.

(b) Structural effects of deficiency. All that need be said under this heading is that in the absence of adequate amounts of vitamin. $C$ the formative cells of the body, (such as the odontoblasts, ameloblasts, cementoblasts, osteoblasts) lose their 
normal functional activity, and cease to lay down the normal type of new tissue (namely dentine, enamel, cement, bone). A particular instance of this is the well-known fact that with a deficiency of vitamin $\mathrm{C}$ the normal production of collagen is impaired.

(c) Specific chemical effects. It is clearly established that vitamin C is involved in two distinct chemical reactions, or systems, namely:

(i) the conversion of folic acid to folinic acid,

(ii) the metabolism of tyrosine and related substances. An additional point here, as suggested by the new findings of King (1953), is that in vitamin C deficiency cholesterol metabolism may also be affected. Apart from this, little is definite.

\section{Adrenal function}

The fact that the administration of a dose of ACTH is followed by a temporary fall in the level of ascorbic acid in the adrenal gland (Sayers, Sayers, Lewis \& Long, I944), suggests that vitamin $\mathrm{C}$ may be related in some way to adrenal function. This idea is further supported by the consideration that vitamin $\mathrm{C}$ is present in extraordinarily high concentration in the adrenal, both in the medulla and the cortex. However, the attempts of my colleagues and myself to find evidence of a consistent relation between $\mathrm{ACTH}$ (or cortisone) function and vitamin $\mathrm{C}$ requirements have so far led to essentially negative conclusions (Harris, Bland, Hughes \& Constable, I953). According to C. P. Stewart and others, $A C ' T H$ and cortisone may affect the equilibrium between ascorbic and dehydroascorbic acids in the blood, in human subjects (see Stewart, Horn \& Robson, 1953a,b); yet our own tests failed to show any essential change in the ratio of ascorbic acid to dehydroascorbic acid in the adrenals of guinea-pigs after an injection of ACTH.

\section{CONCLUSION}

From what has been said, it would seem helpful, then, if, in our discussions and in future work, some particular consideration could be given to these three problems: (I) the quantitative requirements for the vitamin, (2) the reason for its apparently 'uneven' distribution, and (3) the detailed nature of the specific biochemical system or systems in which the vitamin functions and whose derangement, presumably, leads to scurvy.

\section{REFERENCES}

Banerji, G. G. \& Harris, L. J. (1939). Biochem. F. 33, 1346.

Bueding, E., Stein, M. H. \& Wortis, H. (194I). Ұ. biol. Chem. 140, 697.

Crandon, J. H., Mikal, S. \& Landeau, R. (1953). Proc. Nutr. Soc. 12, 273.

Harris, L. J. (1940). Rep. Progr. Chem. 37, 387.

Harris, L. J., Bland, M. N., Hughes, R. E. \& Constable, B. J. (1953). Lancet, 264, I02 I.

King, C. G. (1953). Proc. Nutr. Soc. 12, 219.

League of Nations: Technical Commission on Nutrition (1938). Bull. Hlth Org. L.o.N. 7, 470.

National Research Council (1948). Repr. nat. Res. Coun., Wash., no. 129. Quoted in Nutr. Rev. (1948). 6, 319.

Sayers, G., Sayers, M. A., Lewis, H. K. \& Long, C. N. H. (1944). Proc. Soc. exp. Biol., N.Y., 55, 238.

Shils, M. E., Day, H. G. \& McCollum, E. V. (I941). Y. biol. Chem. 139, 145.

Stewart, C. P., Horn, D. B. \& Robson, J. S. (1953a). Proc. Nutr. Soc. 12, 300.

Stewart, C. P., Horn, D. B. \& Robson, J. S. (1953b). Biochem. F. 53, 254.

Williams, R, D., Mason, H. L. \& Wilder, Z. M. (1943), f. Nutr. 25, 71 . 